2016-07

\title{
Derivation of water quality guidelines for priority pharmaceuticals
}

\author{
Kumar, A
}

http://hdl.handle.net/10026.1/5254

10.1002/etc.3336

Environmental Toxicology and Chemistry

All content in PEARL is protected by copyright law. Author manuscripts are made available in accordance with publisher policies. Please cite only the published version using the details provided on the item record or document. In the absence of an open licence (e.g. Creative Commons), permissions for further reuse of content should be sought from the publisher or author. 
4 Derivation of water quality guidelines for priority pharmaceuticals

5 Anupama Kumar*

$6 \quad *$ Correponding author

7 Environmental Contaminant Mitigation and Technologies

$8 \quad$ CSIRO Land and Water Flagship

9 Private Bag No. 2, Glen Osmond, SA 5064, Australia

10 Tel: $+61-8-83038597$

11 Fax: $+61-8-83038565$

12 E-mail: anupama.kumar@csiro.au

13 Total number of words -6501 


\section{DERIVATION OF WATER QUALITY GUIDELINES FOR PRIORITY}

\section{PHARMACEUTICALS}

17 Anupama Kumar $^{+*}$, Graeme E. Batley ${ }^{\ddagger}$, Bhanu Nidumolu ${ }^{\dagger}$ and Thomas H. Hutchinson ${ }^{\S}$

18

$19{ }^{\dagger}$ Centre for Environmental Contaminants Research, CSIRO Land and Water Flagship, PMB

20 2, Glen Osmond, Adelaide, SA 5064, Australia

$21{ }^{\ddagger}$ Centre for Environmental Contaminants Research, CSIRO Land and Water Flagship,

22 Locked Bag 2007, Kirrawee, NSW 2232, Australia

$23{ }^{\S}$ University of Plymouth, Drake Circus, Plymouth PL4 8AA, United Kingdom

24 
$25 *$ To whom correspondence may be addressed

26 Anupama.kumar@csiro.au

27 
28 Abstract- High reliability water quality guideline values (GVs) have been derived for four pharmaceuticals, carbamazepine, diclofenac, fluoxetine and propanolol in fresh waters using a Burr Type III distribution applied to species sensitivity distributions (SSDs) of chronic toxicity data. Data were quality assured and had to meet acceptability criteria for 'chronic' NOEC or EC10 endpoints including population relevance (namely, effect endpoints based on development, growth, reproduction and survival). Biomarker response data (e.g. biochemical, histological or molecular responses) were excluded from the derivation as they are typically not directly relevant to population-related impacts. The derived GVs for $95 \%$ species protection were $4.3,770,1.6$ and $14 \mu \mathrm{g} / \mathrm{L}$ for carbamazepine, diclofenac, fluoxetine and propranolol, respectively. These values significantly higher than the low reliability values derived for the European Commission, Switzerland or Germany that are based on the application of assessment factors to the most sensitive experimental endpoint (which may include biochemical, histological or molecular biomarker responses). The GVs derived in this exercise were not exceeded in recent data for Australian rivers and streams receiving pharmaceutical containing effluents from WWTPs.

\section{Keywords}

44 Pharmaceutical, carbamazepine, diclofenac, fluoxetine, propanolol 


\section{INTRODUCTION}

Our growing dependence on pharmaceuticals, and their increased availability to consumers, means that a number of the commonly used products are becoming detectable constituents of wastewaters $[1,2]$. Depending on the effectiveness of the wastewater treatment process, there are real prospects for these products to reach natural water systems, with the potential for effects on aquatic ecosystem health. Ecotoxicological investigations have been carried out for many of the popularly used pharmaceuticals, however, there have been limited attempts to derive water quality guidelines that enable regulatory agencies to determine whether measured environmental concentrations pose a concern.

This paper collates the available data for four pharmaceuticals, carbamazepine, diclofenac, fluoxetine and propranolol, and derives high reliability guideline values for ecosystem protection of 99,95 and $90 \%$ of species using species sensitivity distributions (SSDs) [3]. The latest revisions to the guideline derivation protocols [4] were applied. These involve:

(i) Using effects endpoints for development, growth, reproduction or survival and focussing on chronic EC10 data, where available, rather than NOEC data and excluding biomarker responses (e.g. biochemical, histological or molecular responses);

(ii) Ensuring that all toxicity data meet the required definitions of chronic tests, in particular, for juvenile fish tests, exposure duration should be $\geq 21$ days and $\geq 7$ days for fish embryo tests;

(iii) High reliability guideline values require 8 or more data points for chronic exposure (no conversions of acute data to chronic) representing at least 4 taxonomic groups;

(iv) The goodness of fit of data to the Burr Type III distribution used in the SSD being acceptable; and 
(v) Careful evaluation of all data to ensure they meet acceptability criteria (Batley et al., 2013).

The basic data for each of the pharmaceuticals are summarised in Table 1.

\section{EXPERIMENTAL}

A thorough review of the literature was undertaken for all toxicity data relating to carbamazepine, diclofenac, fluoxetine and propanolol and added to a new dataset determined in our laboratories [5]. Since our priority is ecological protection based on populationrelevant endpoints, adverse effects on development, growth, reproduction and survival were used to derive NOEC or EC10 values, as per the recommendation by Hutchinson et al. [6].

This approach recognizes that biomarkers responses based on biochemical, histological and molecular endpoints may be highly useful for exposure monitoring $[7,8]$ and also in developing adverse outcome pathways to help prioritize appropriate testing strategies for ecotoxicology research and risk assessment [9]. Data were sorted into acute and chronic tests, with the objective of obtaining at least 8 chronic NOEC or EC10 data points for species from 4 or more taxonomic groups. If this was achieved, acute data and chronic data having other endpoints (e.g. EC50 or LOECs) were discarded, otherwise lower reliability guidelines could be generated using a combination of converted acute data (using an ACR or default value of 10) and chronic data. A quality check of the data as described by Hobbs et al. [10] was then undertaken and only data of high or acceptable quality were retained as recommended for guideline derivation in Australia and New Zealand [4].

Data were then screened to ensure that the endpoints reported were acceptable as chronic tests according to agreed criteria $[4,10]$. An SSD was then obtained from the data set 
using the BurrliOz Version 2 software to derive guideline values $(\mathrm{GVs})$ that were protective of 99, 95 and 90\% of species (PC99, PC95 and PC90) with 50\% confidence.

\section{RESULTS AND DISCUSSION}

\section{Carbamazepine}

A review of the literature found acute toxicity data reported for 6 species, and chronic toxicity for 17 species. Of these, acceptable chronic toxicity data were available for 11 species ( 2 cladocerans, 2 green algae, 1 blue-green algae, 1 diatom, 1 midge, 1 rotifer, 1 cnidarian and 2 fish) representing 8 taxonomic groups (Table 2). The cladoceran, Ceriodaphnia dubia, was the most sensitive, with an EC10 of $25 \mu \mathrm{g} / \mathrm{L}$ [11]. The data distribution using a Burr Type III fit in the SSD was such that it had a long tail (Figure 1), which meant that a $99 \%$ protection GV could not be determined. The $95 \%$ protection GV was $4.3 \mu \mathrm{g} / \mathrm{L}$ (Table 6).

Carbamazepine enters the environment largely through discharges from wastewater treatment plants, in which it is not effectively removed $[12,13]$. It has been detected in discharges from German plants at concentrations up to $6.3 \mu \mathrm{g} / \mathrm{L}$ [14]. Loos et al. [15] reported a mean concentration of $250 \mathrm{ng} / \mathrm{L}$ (maximum $12 \mu \mathrm{g} / \mathrm{L}$ ) in studies of 122 European river waters. Indian rivers contained 6-128 ng/L [16] while in Spanish rivers 80-3090 ng/L [17] and in the Pearl River in China, $43 \mathrm{ng} / \mathrm{L}$ [18]. It has a relative long half-life of 38 days in natural waters in the presence of sunlight, with photolysis being the major degradation pathway [12]. Tixier et al. [19] reported a half-life of 63 days in Lake Greifensee in Germany, indicating that it was relatively persistent.

In all cases, detected concentrations in receiving waters were below the derived GV. The guidelines recommended in Switzerland and Germany [20, 21] are considerably lower 
120 (Table 7). The Swiss environmental quality standard (EQS) of $0.5 \mu \mathrm{g} / \mathrm{L}$ was derived by

121

122

applying an assessment factor of 50 to the most sensitive reliable endpoint, that for reproduction of Ceriodaphnia dubia $(25 \mu \mathrm{g} / \mathrm{L})$ [22]. The available fish data were only for a 10-d exposure and considered not acceptable for a chronic test, although in Australia and New Zealand, the 7-d test is acceptable for fish embryos and a 21-d test required for juvenile fish [4]. In the Swiss study, the scope of the data analysis included both adverse effects data and biomarker responses in contrast to our focus solely on population-relevant effects [22]. Their GV is clearly of low reliability compared to that derived in this paper. Ferrari et al. [23] using a limited dataset and a log-normal distribution in a SSD, determined $95 \%$ protection value (reported as a hazardous concentration to $5 \%$ of species, HC5) of $2.1 \mu \mathrm{g} / \mathrm{L}$. (Table 7), comparable to our value of $4.3 \mu \mathrm{g} / \mathrm{L}$ with a large dataset.

\section{Diclofenac}

Of 13 chronic data for diclofenac, 11 had EC10 or NOEC values suitable for GV derivation. These comprised 2 cladocerans, 1 diatom, 2 green algae, 1 blue-green algae, 1 rotifer, 1 angiosperm, 1 arthropod and 2 fish, representing 8 taxonomic groups. The most sensitive species was the midge, Chironomus tepperi with an EC10 of $760 \mu \mathrm{g} / \mathrm{L}$ [5].

diclofenac in ultrapure water to sunlight and noted an increase in toxicity measured as growth inhibition, with time over 6 days, with the EC50 decreasing from $46.3 \mathrm{mg} / \mathrm{L}$ to $23 \mu \mathrm{g} / \mathrm{L}$ after 6 days. There was a rapid decrease in diclofenac concentrations due to photodegradation and the enhanced toxicity was clearly due to the presence of degradation products. These data were not included as the tests were not conducted in natural waters and the $\mathrm{pH}$ was not 
recorded, nor EC10 values calculated. It is unclear how the results relate to actual field conditions.

Concentrations in the range 310-930 ng/L have been detected in the effluents from a

Swiss wastewater treatment plant, with concentrations only marginally reduced during passage through the plant [25]. Diclofenac has been detected at $<1-12 \mathrm{ng} / \mathrm{L}$ in Swiss lakes and 11-310 ng/L in a nearby river [25] and from 110-220 ng/L in the Höje River in Sweden downstream of a WWTP [26]. Photolysis is the major degradation pathway with half-lives near $3 \mathrm{~h}$ at summer temperatures [24] (Buser et al. [25] reported $0.9 \mathrm{~h}$ ), but up to 2 days in winter in some locations [27]. Diclofenac is ionised at the $\mathrm{pH}$ of most waters $(\mathrm{pKa}=4.2)$, so is not readily volatilised, nor does it readily attach to particulates [25].

The measured concentrations are below the GV derived in this study (Table 6), but would exceed the proposed EQS for the European Commission (reported in Europe (Johnson et al., 2013) (Table 7). A discussion paper on the EU guidelines [28] indicated that these values are derived by applying an assessment factor of 10 to the lowest acceptable NOEC, for a fish. For rainbow trout, both Schwaiger et al. [29] and Triebskorn [30] reported a LOEC of $1 \mu \mathrm{g} / \mathrm{L}$ for a histopathological effect, while the latter referred to a threshold of $5 \mu \mathrm{g} / \mathrm{L}$ for histopathological lesions. A NOEC of $0.5 \mu \mathrm{g} / \mathrm{L}$ was reported by Hoeger et al. [31] for monocyte infiltration/accumulation in livers of brown trout exposed to diclofenac for 21 days. They concluded that the adverse effects in various organs could 'possibly compromise fish health'. The EQS of $0.05 \mu \mathrm{g} / \mathrm{L}$ proposed by the Swiss Ecotox Centre [32] was based on the application of an assessment factor of 10 to the above NOEC for brown trout.

The current Australian and New Zealand approach to biomarker endpoints of this type is that they should not be used in the derivation of water quality guidelines, unless their ecological relevance can be demonstrated [4]. This approach is consistent with that of Hutchinson et al. [33] who advocated that biomarker responses or signals (such as 
vitellogenin, secondary sexual characteristics, gonadosomatic index, gonad histology, plasma steroids, enzyme induction and gene expression) may provide valuable mechanistic signals to guide chronic testing for adverse effects and, at present, should not be used to directly derive water quality guidelines. Moreover, it is recognized that interpretation of many biomarkers responses in aquatic organisms is highly complex [33-35]. Acceptable population-relevant effects endpoints include survival, length, weight, development, fecundity, fertilisation rate, hatching success and sex ratios. The focus on population-relevant endpoints for setting GVs for pharmaceuticals is also proposed by Caldwell et al. [36, 37].

The use of an assessment factor results in a conservative, very low reliability GV. By contrast, the GV derived in this study would be classified as high reliability based on the criteria being adopted for Australian and New Zealand water quality guideline derivation [4]. Using a limited data set, Ferrari et al. [23] applied a log normal distribution in an SSD to derive an $\mathrm{HC} 5$ that protected $95 \%$ of species that was of the same order of magnitude as our value of $770 \mu \mathrm{g} / \mathrm{L}$.

SCHER [28] raised a concern regarding the solubility of diclofenac being exceeded in some of the toxicity tests, however, data from Llinas et al. [38] suggest that this would only be an issue in mildly acidic solutions below the diclofenac $\mathrm{pKa}$. At the $\mathrm{pH}$ of natural waters, solubility limitations would not be an issue.

\section{Fluoxetine}

There is a large toxicity database for fluoxetine, comprising both acute and chronic tests as well as others based on behavioural and biomarker endpoints. Of these only 13 reported chronic NOEC or EC/IC10 endpoints, comprising 6 green algae, 1 arthropod, 1 angiosperm, 3 crustaceans, 1 gastropod and 1 fish, representing 6 taxonomic groups (Table 4). Oakes et al. [39] found that the green alga Desmodesmus subspicatus was the most 
sensitive species to fluoxetine with a NOEC was $\leq 0.6 \mu \mathrm{g} / \mathrm{L}$. Given that NOECs are not a reliable endpoint, most jurisdictions, including Australia and New Zealand, recommend the use of EC/IC10 values as a more defensible alternative [4]. In the supplementary information to Oakes et al. [39], the plotted dose response curve showed an IC10 of $1 \mu \mathrm{g} / \mathrm{L}$ and so this was included in the database used in this study. Along with this species, the New Zealand mud snail, Potamopygus antipodarum was also very sensitive (Table 4) [40, 41].

The malformation endpoint for the African clawed frog, Xenopus laevis [42] (Table 4) was deemed unacceptable for use in GV derivation as many non-contaminant factors can lead to malformations The 7-d juvenile fish data for fathead minnow [43] were considered acute and not chronic according to the Australian and New Zealand data selection criteria [4] which require a $21-d$ test, so this too was not included.

Fluoxetine is a racemate, a mixture of two sterioisomers with mirror-image structures [4]. The $(R)$-enantiomer is known as dextro-propranolol. The $(S)$-enantiomer is known as levo-fluoxetine. The most common form is as a racemic mixture $(1: 1)$ of the sterioisomers, supplied as the hydrochloride. To date only one study has examined the chronic toxicity of the sterioisomers and found that $(S)$-fluoxetine was more toxic than $(R)$-fluoxetine to fathead minnow, Pimephales promelas, while there was no significant difference in the responses of Daphnia magna [4]. Fluoxetine photodegradation has a relatively long half-life (160 days) [44] and its relatively high $\mathrm{K}_{\mathrm{ow}}$ means that it binds preferentially to particulate organic matter. Measured concentrations of fluoxetine in natural waters are typically in the $\mathrm{ng} / \mathrm{L}$ range. Kolpin et al. [45] reported a median concentration of $12 \mathrm{ng} / \mathrm{L}$ for a range of US streams, and similar values have been reported for waters in Canada and the UK [39]. WWTP effluent concentrations are typically $<500 \mathrm{ng} / \mathrm{L}$ [46-48]. 

species protection. No reported EQS values could be found, however, a number of studies reported predicted no effects concentrations (PNECs) for fluoxetine in surface waters. These were all obtained by applying assessment factors to the most sensitive data (Table 7). Thus Oakes et al. [39] obtained a PNEC of $0.012 \mu \mathrm{g} / \mathrm{L}$ by applying a factor of 50 to the $D$. subspicatus data. Montforts [49] reported a PNEC of $0.031 \mu \mathrm{g} / \mathrm{L}$ using a factor of 1000 with algal toxicity data. Grung et al. [50] reported a PNEC of $0.004 \mu \mathrm{g} / \mathrm{L}$, while Verlicchi et al. [2] reported a PNEC of $0.05 \mu \mathrm{g} / \mathrm{L}$. All of these values are conservative and of very low reliability.

Sumpter et al. [51] have discussed the fact that both vertebrates and invertebrates use serotonin as a neurotransmitter and, as such, fluoxetine as a serotonin reuptake inhibitor, may have effects on fish (and invertebrate) behaviour (e.g. swimming speed, schooling behaviour). Such non-standard endpoints have not been considered on our GV derivation.

\section{Propranolol}

Data were obtained for 2 cladocerans, 1 diatom, 2 green algae, 1 blue-green algae, 1 rotifer, 1 angiosperm, 1 arthropod and 3 fish, representing 8 taxonomic groups. Of these, the fathead minnow, Pimephales promelas [53] and the cladoceran, Ceriodaphnia dubia, were 
the most sensitive [54]. Like fuoxetine, propranolol is a racemate [55], with the most common form a racemic mixture $(1: 1)$ of the sterioisomers, supplied as the hydrochloride.

Propranolol has been detected in WWTP effluents in Germany at a median concentration of $170 \mathrm{ng} / \mathrm{L}$ (290 ng/L maximum) [14] and in Sweden near $30 \mathrm{ng} / \mathrm{L}$ [26]. Downstream river water concentrations were closer to $12 \mathrm{ng} / \mathrm{L}$ (590 ng/L maximum) and 10 ng/L respectively. High concentrations are unlikely to persist as the laboratory-determined half-life for photolytic decomposition was $1.1 \mathrm{~h}$ [56]. For sunlight exposure, Liu et al. [57] extrapolating from laboratory studies calculated a half-life closer to 1 day in summer and 8 days in winter, with photodegradation being up to 19 times faster than biodegradation.

Our study yielded a high reliability guideline value for propranolol of $14 \mu \mathrm{g} / \mathrm{L}$. This is almost 100-fold higher than the value recommended for Switzerland [32]. Their low reliability EQS of $0.16 \mu \mathrm{g} / \mathrm{L}$ (Ecotox Centre, 2013d) used an assessment factor of 50 applied to a NOEC of $8 \mu \mathrm{g} / \mathrm{L}$ for Ceriodaphnia dubia reproduction [54] (although the value reported in Ferrari et al. was actually $9 \mu \mathrm{g} / \mathrm{L})$.

(1)

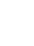

\section{CONCLUSIONS}

High reliability GVs have been derived for carbamazepine, diclofenac, fluoxetine and propanolol in fresh waters applying a Burr Type III distribution in SSDs of chronic toxicity data (NOECs or EC10s). Data were quality assured and had to meet acceptability criteria for 'chronic' endpoints. Sub-chronic biomarker data were excluded from the derivation and only data for ecologically relevant, population-related effects were included. The derived GVs for 95\% species protection were $4.3,770,1.6$ and $14 \mu \mathrm{g} / \mathrm{L}$ respectively, for the four pharmaceuticals. These values significantly higher than the low reliability values derived for the European Commission, Switzerland or Germany that are based on the application of 

assessment factors to the most sensitive endpoint. They are not exceeded in recent data for

266 rivers and streams receiving pharmaceutical containing effluents from WWTPs.

267 
272 Conflict of interest - The authors declare no conflict of interest. 


\section{REFERENCES}

1. SRU. 2007. Pharmaceuticals in the Environment. Statement of the German Advisory Council on the Environment (SRU), Berlin, Germany, $51 \mathrm{pp}$.

2. Verlicchi P, Al Aukidy M, Zambello E. 2012. Occurrence of pharmaceutical compounds in urban wastewater: Removal, mass load and environmental risk after a secondary treatmentA review. Sci Total Environ 429:123-155.

3. ANZECC/ARMCANZ 2000. Australian and New Zealand guidelines for fresh and marine water quality. Australian and New Zealand Environment and Conservation Council, Agriculture and Resource Management Council of Australia and New Zealand: Canberra, Australia.

4. Batley GE, Warne, M. StJ., Van Dam, R., Chapman, J.C., Fox, D.R., Hickey, C.W. and Stauber, J.L. 2014. Technical rationale for changes to the method for deriving Australian and New Zealand water quality guideline values for toxicants. CSIRO Water for a Healthy Country Flagship Report, prepared for the Department of the Environment, Canberra, Australia , 39 pp.

5. Kumar A, Williams M, Bain P, Doan H, Gonzago D and Gregg A. 2013. Environmental risk assessment of selected human pharmaceuticals. CSIRO Water for a Healthy Country Flagship Report, prepared for the NSW Environmental Trust, Sydney, NSW, Australia. 49 pp.

6. Hutchinson TH, Ankley GT, Segner H, Tyler CR. 2006. Screening and testing for endocrine disruption in fish - Biomarkers as "signposts," not "traffic lights," in risk assessment. Environ Health Persp 114:106-114.

7. Sumpter JP, Jobling S. 1995. Vitellogenesis as a biomarker for estrogenic contamination of the aquatic environment. Environ Health Perspect 103 Suppl 7:173-178.

8. Tyler CR, Spary C, Gibson R, Santos EM, Shears J, Hill EM. 2005. Accounting for differences in estrogenic responses in rainbow trout (Oncorhynchus mykiss : Salmonidae) and roach (Rutilus rutilus : Cyprinidae) exposed to effluents from wastewater treatment works. Environ Sci Technol 39:2599-2607.

9. Ankley GT, Bennett RS, Erickson RJ, Hoff DJ, Hornung MW, Johnson RD, Mount DR, Nichols JW, Russom CL, Schmieder PK, Serrrano JA, Tietge JE, Villeneuve DL. 2010. Adverse outcome pathways: a conceptual framework to support ecotoxicology research and risk assessment. Environ Toxicol Chem 29:730-741. 
10. Hobbs DA, Warne MSJ, Markich SJ. 2005. Evaluation of criteria used to assess the quality of aquatic toxicity data. Integr Environ Assess Manag 1:174-80.

11. Ferrari B,Ferard JF. 1996. Effects of nutritional renewal frequency on survival and reproduction of Ceriodaphnia dubia. Environ Toxicol Chem 15:765-770.

12. Andreozzi R, Marotta R, Pinto G, Pollio A. 2002. Carbamazepine in water: persistence in the environment, ozonation treatment and preliminary assessment on algal toxicity. Water Res 36:2869-2877.

13. Calisto V,Esteves VI. 2012. Adsorption of the antiepileptic carbamazepine onto agricultural soils. J Environ Monitor 14:1597-1603.

14. Ternes TA. 1998. Occurrence of drugs in German sewage treatment plants and rivers. Water Res 32:3245-3260.

15. Loos R, Gawlik BM, Locoro G, Rimaviciute E, Contini S, Bidoglio G. 2009. EU-wide survey of polar organic persistent pollutants in European river waters. Environ Poll 157:561-568.

16. Ramaswamy BR, Shanmugam G, Velu G, Rengarajan B, Larsson DGJ. 2011. GC-MS analysis and ecotoxicological risk assessment of triclosan, carbamazepine and parabens in Indian rivers. J Hazard Mater 186:1586-1593.

17. Ginebreda A, Munoz I, Lopez de Alda M, Brix R, Lopez-Doval J, Barcelo D. 2010.

Environmental risk assessment of pharmaceuticals in rivers: Relationships between hazard indexes and aquatic macroinvertebrate diversity indexes in the Llobregat River (NE Spain). Environ Int 36:153-162.

18. Zhao J-L, Ying G-G, Liu Y-S, Chen F, Yang J-F, Wang L, Yang X-B, Stauber JL, Warne MSJ. 2010. Occurrence and a screening-level risk assessment of human pharmaceuticals in the pearl river system, South China. Environ Toxicol Chem 29:1377-1384.

19. Tixier C, Singer HP, Oellers S, Muller SR. 2003. Occurrence and fate of carbamazepine, clofibric acid, diclofenac, ibuprofen, ketoprofen, and naproxen in surface waters. Environ Sci Technol 37:1061-1068.

20. Ecotox Centre. 2013. Quality Standards for Organic Trace Substances in Surface Water. Swiss Centre for Applied Ecotoxicology, Dübendorf, Switzerland, 13 pp.

21. Arle J, Blondzik K, Claussen U, Duffek A, Heidemeier J, Hilliges F, Hoffmann A, Koch K, Leujak W, Mohaupt V, Naumann S, Richter S, Ringeltaube P, Schilling P, Schroeter-Kermani C, 
Ullrich A, Wellmitz J, Wolter R. 2010. Water Quality. In Water Resource Management in Germany, ed. Irmer U, Blondzik, Germany.

22. Ecotox Centre. 2013. EQS-proposal of Ecotox Centre for: carbamazepine.Swiss Centre for Applied Ecotoxicology, Dübendorf, Switzerland, 27 pp.

23. Ferrari B, Paxeus N, Lo Giudice R, Pollio A, Garric J. 2003. Ecotoxicological impact of pharmaceuticals found in treated wastewaters: study of carbamazepine, clofibric acid, and diclofenac. Ecotox Environ Saf 55, 359-370.

24. Schmitt-Jansen M, Bartels P, Adler N, Altenburger R. 2007. Phytotoxicity assessment of diclofenac and its phototransformation products. Anal Bioanal Chem 387:1389-1396.

25. Buser HR, Poiger T, Muller MD. 1998. Occurrence and fate of the pharmaceutical drug diclofenac in surface waters - rapid photodegradation in a lake. Environ Sci Technol 32:34493456.

26. Bendz D, Paxeus NA, Ginn TR, Loge FJ. 2005. Occurrence and fate of pharmaceutically active compounds in the environment, a case study: Hoje River in Sweden. J Hazardous Mats 122:195-204.

27. Andreozzi R, Marotta R, Paxeus N. 2003. Pharmaceuticals in STP effluents and their solar photodegradation in aquatic environment. Chemosphere 50:1319-1330.

28. SCHER 2011. Opinion on "Chemicals and the Water Framework Directive: Draft Environmental Quality Standards" diclofenac European Commission, Scientific Committee on Health and Environmental Risks, 8 pp.

29. Schwaiger J, Ferling H, Mallow U, Wintermayr H, Negele RD. 2004. Toxic effects of the nonsteroidal anti-inflammatory drug diclofenac Part 1: histopathological alterations and bioaccumulation in rainbow trout. Aquat Toxicol 68:141-150.

30. Triebskorn R, Casper H, Heyd A, Eikemper R, Kohler HR, Schwaiger J. 2004. Toxic effects of the non-steroidal anti-inflammatory drug diclofenac Part II. Cytological effects in liver, kidney, gills and intestine of rainbow trout (Oncorhynchus mykiss). Aquat Toxicol 68:151166.

31. Hoeger B, Kollner B, Dietrich DR, Hitzfeld B. 2005. Water-borne diclofenac affects kidney and gill integrity and selected immune parameters in brown trout (Salmo trutta f. fario). Aquat Toxicol 75:53-64. 
32. Ecotox Centre., 2013. EQS-proposal of Ecotox Centre for: diclofenac. Swiss Centre for Applied Ecotoxicology, Dübendorf, Switzerland. 16 pp.

33. Hutchinson TH, Ankley GT, Segner H, Tyler CR. 2006. Screening and testing for endocrine disruption in fish-biomarkers as "signposts," not "traffic lights," in risk assessment. Environ Health Persp 114 Suppl 1:106-14.

34. Wolf JC, Dietrich DR, Friederich U, Caunter J, Brown AR. 2004. Qualitative and quantitative histomorphologic assessment of fathead minnow Pimephales promelas gonads as an endpoint for evaluating endocrine-active compounds: A pilot methodology study. Toxicol Pathol 32:600-612.

35. Wolf JC, Ruehl-Fehlert C, Segner HE, Weber K, Hardisty JF. 2014. Pathology working group review of histopathologic specimens from three laboratory studies of diclofenac in trout. Aquat Toxicol 146:127-136.

36. Caldwell DJ, Mastrocco F, Hutchinson TH, Lange R, Heijerick D, Janssen C, Anderson PD, Sumpter JP. 2008. Derivation of an aquatic predicted no-effect concentration for the synthetic hormone, 17 alpha-ethinyl estradiol. Environ Sci Technol 42:7046-7054.

37. Caldwell DJ, Mastrocco F, Anderson PD, Lange R, Sumpter JP. 2012. Predicted-no-effect concentrations for the steroid estrogens estrone, 17beta-estradiol, estriol, and 17alphaethinylestradiol. Environ Toxicol Chem 31:1396-406.

38. Llinas A, Burley JC, Box KJ, Glen RC, Goodman JM. 2007. Diclofenac solubility: Independent determination of the intrinsic solubility of three crystal forms. J Med Chem 50:979-983.

39. Oakes KD, Coors A, Escher BI, Fenner K, Garric J, Gust M, Knacker T, Kuester A, Kussatz C, Metcalfe CD, Monteiro S, Moon TW, Mennigen JA, Parrott J, Pery ARR, Ramil M, Roennefahrt I, Tarazona JV, Sanchez-Argueello P, Ternes TA, Trudeau VL, Boucard T, Van Der Kraak GJ, Servos MR. 2010. Environmental risk assessment for the serotonin re-uptake inhibitor fluoxetine: case study using the European Risk Assessment Framework. Integr Environ Assess Manag 6:524-539.

40. Pery ARR, Gust M, Vollat B, Mons R, Ramil M, Fink G, Ternes T, Garric J. 2008. Fluoxetine effects assessment on the life cycle of aquatic invertebrates. Chemosphere 73:300-304.

41. Nentwig G. 2007. Effects of pharmaceuticals on aquatic invertebrates. Part II: The antidepressant drug fluoxetine. Arch Environ Contam Toxicol 52:163-170.

42. Richards SM, Cole SE. 2006. A toxicity and hazard assessment of fourteen pharmaceuticals to Xenopus laevis larvae. Ecotoxicol 15:647-656. 
43. Stanley JK, Ramirez AJ, Chambliss CK, Brooks BW. 2007. Enantiospecific sublethal effects of the antidepressant fluoxetine to a model aquatic vertebrate and invertebrate. Chemosphere 69:9-16.

44. Kwon J-W, Armbrust KL. 2006. Laboratory persistence and fate of fluoxetine in aquatic environments. Environ Toxicol Chem 25:2561-2568.

45. Kolpin DW, Furlong ET, Meyer MT, Thurman EM, Zaugg SD, Barber LB, Buxton HT. 2002. Pharmaceuticals, hormones, and other organic wastewater contaminants in U.S. streams, 1999-2000: a national reconnaissance. Environ Sci Technol 36:1202-11.

46. Bringolf RB, Heltsley RM, Newton TJ, Eads CB, Fraley SJ, Shea D, Cope WG. 2010. environmental occurrence and reproductive effects of the pharmaceutical fluoxetine in native freshwater mussels. Environ Toxicol Chem 29:1311-1318.

47. Brooks BW, Foran CM, Richards SM, Weston J, Turner PK, Stanley JK, Solomon KR, Slattery M, La Point TW. 2003. Aquatic ecotoxicology of fluoxetine. Toxicol Lett 142:169-183.

48. Brooks BW, Turner PK, Stanley JK, Weston JJ, Glidewell EA, Foran CM, Slattery M, La Point TW, Huggett DB. 2003. Waterborne and sediment toxicity of fluoxetine to select organisms. Chemosphere 52:135-142.

49. Montforts MHMM. 2005. The trigger values in the environmental risk assessment for (veterinary) medicines in the European Union: a critical appraisal, Bilthoven, The Netherlands. 45 pp.

50. Grung M, Heimstad ES, Moe M, Schlabach M, Svenson A, Thomas K, and Woldegiorgis A. 2007. Human and Veterinary Pharmaceuticals, Narcotics, and Personal Care Products in the Environment Current State of Knowledge and Monitoring Requirements. Norwegian Pollution Control Authority Report TA-2325, Oslo, Norway, 98 pp.

51. Sumpter JP, Donnachie RL, Johnson AC. 2014. The apparently very variable potency of the anti-depressant fluoxetine. Aquat Toxicol 151:57-60.

52. Cleuvers M. 2005. Initial risk assessment for three beta-blockers found in the aquatic environment. Chemosphere 59:199-205.

53. Giltrow E, Eccles PD, Winter MJ, McCormack PJ, Rand-Weaver M, Hutchinson TH, Sumpter JP. 2009. Chronic effects assessment and plasma concentrations of the beta-blocker propranolol in fathead minnows (Pimephales promelas). Aquat Toxicol 95:195-202. 
54. Ferrari B, Mons R, Vollat B, Fraysse B, Paxeus N, Lo Giudice R, Pollio A, Garric J. 2004. Environmental risk assessment of six human pharmaceuticals: Are the current environmental risk assessment procedures sufficient for the protection of the aquatic environment? Environ Toxicol Chem 23:1344-1354.

55. Stanley JK, Ramirez AJ, Mottaleb M, Chambliss CK, Brooks BW. 2006. Enantiospecific toxicity of the beta-blocker propranolol to Daphnia magna and Pimephales promelas. Environ Toxicol Chem 25:1780-1786.

56. Lin AYC,Reinhard M. 2005. Photodegradation of common environmental pharmaceuticals and estrogens in river water. Environ Toxicol Chem 24:1303-1309.

57. Liu QT, Riddle AM, Robinson PF, Gray N. and Murray-Smith R. 2004. Roles of partitioning and phototransformation in predicting the fate and movement of pharmaceuticals in UK and US rivers. In Proceedings of the 4th International Conference on Pharmaceuticals and Endocrinedisrupting Chemicals in Water, National Groundwater Association, UK.

58. Kwon JW,Armbrust KL. 2008. Aqueous solubility, n-octanol-water partition coefficient, and sorption of five selective serotonin reuptake inhibitors to sediments and soils. Bull Environ Contam Toxicol 81:128-35.

59. Mohsen-Nia M, Ebrahimabadi AH, Niknahad B. 2012. Partition coefficient n-octanol/water of propranolol and atenolol at different temperatures: Experimental and theoretical studies. $J$ Chem Thermodyn 54:393-397.

60. Harada A, Komori K, Nakada N, Kitamura K, Suzuki Y. 2008. Biological effects of PPCPs on aquatic lives and evaluation of river waters affected by different wastewater treatment levels. Water Sci Technol 58:1541-1546.

61. Jos A, Repetto G, Rios JC, Hazen N, Molero ML, del Peso A, Salguero M, Fernandez-Freire P, Perez-Martin JM, Camen A. 2003. Ecotoxicological evaluation of carbamazepine using six different model systems with eighteen endpoints. Toxicol in Vitro 17:525-532.

62. Quinn B, Gagne F, Blaise C. 2008. An investigation into the acute and chronic toxicity of eleven pharmaceuticals (and their solvents) found in wastewater effluent on the cnidarians, Hydra attenuata. Sci Total Environ 389, 306-314.

63. Liebig M. 2005. Studies on environmental risk assessment of human pharmaceuticals and ingredients of personal care products in the context of European valuation concepts. Johann Wolfgang Goethe University in Frankfurt am Main, Frankfurt, Germany. 
64. Cleuvers M. 2004. Mixture toxicity of the anti-inflammatory drugs diclofenac, ibuprofen, naproxen, and acetylsalicylic acid. Ecotox Environ Saf 59:309-315.

65. Han GH, Hur HG, Kim SD. 2006. Ecotoxicological risk of pharmaceuticals from wastewater treatment plants in Korea: Occurrence and toxicity to Daphnia magna. Environ Toxicol Chem 25:265-271.

66. Johnson DJ, Sanderson H, Brain RA, Wilson CJ, Solomon KR. 2007. Toxicity and hazard of selective serotonin reuptake inhibitor antidepressants fluoxetine, fluvoxamine, and sertraline to algae. Ecotox Environ Safety 67:128-139.

67. Christensen AM, Faaborg-Andersen S, Ingerslev F, Baun A. 2007. Mixture and singlesubstance toxicity of selective serotonin reuptake inhibitors toward algae and crustaceans. Environ Toxicol Chem 26:85-91.

68. DeLorenzo ME,Fleming J. 2008. Individual and mixture effects of selected pharmaceuticals and personal care products on the marine phytoplankton species Dunaliella tertiolecta. Arch Environ Contamn Toxicol 54:203-210.

69. Henry TB, Kwon JW, Armbrust KL, Black MC. 2004. Acute and chronic toxicity of five selective serotonin reuptake inhibitors in Ceriodaphnia dubia. Environ Toxicol Chem 23:2229-2233.

70. Liu Q-T, Williams TD, Cumming RI, Holm G, Hetheridge MJ, Murray-Smith R. 2009. Comparative aquatic toxicity of propranolol and its photodegraded mixtures: algae and rotifer screening. Environ Toxicol Chem 28:2622-2631.

71. Huggett DB, Brooks BW, Peterson B, Foran CM, Schlenk D. 2002. Toxicity of select beta adrenergic receptor-blocking pharmaceuticals (beta-blockers) on aquatic organisms. Arch Environ Contam Toxicol 43:229-235.

72. Dzialowski EM, Turner PK, Brooks BW. 2006. Physiological and reproductive effects of beta adrenergic receptor antagonists in Daphnia magna. Arch Environ Contam Toxicol 50:503510.

73. Owen SF, Huggett DB, Hutchinson TH, Hetheridge MJ, Kinter LB, Ericson JF, Sumpter JP. 2009. Uptake of propranolol, a cardiovascular pharmaceutical, from water into fish plasma and its effects on growth and organ biometry. Aquat Toxicol 93:217-224.

74. EC 2011. Proposal for a directive of the European Parliament and of the Council amending Directives 2000/60/EC and 2008/105/EC as regards priority substances in the field of water policyIn European Commission Report COM(2011) 8762012, Brussels, Belgium. 35 pp. 
Table 1. Key properties of the studied pharmaceuticals

\begin{tabular}{|c|c|c|c|c|c|c|}
\hline Pharmaceutical & Chemical Structure & $\begin{array}{c}\text { Common } \\
\text { name }\end{array}$ & $\begin{array}{l}\text { Log } \\
\mathbf{K}_{\mathbf{o w}}\end{array}$ & $\begin{array}{l}\text { Solubility, } \\
\text { mg/L }\end{array}$ & pKa & Reference \\
\hline $\begin{array}{l}\text { Carbamazepine } \\
\text { (anti-convulsant and } \\
\text { mood stabiliser) }\end{array}$ & $\mathrm{MW}=236.3$ & Tegretol & 2.45 & 112 & 13.9 & [54] \\
\hline $\begin{array}{l}\text { Diclofenac (non- } \\
\text { steroidal anti- } \\
\text { inflammatory) }\end{array}$ & $\mathrm{MW}=296.1$ & Voltarin & 4.51 & 2,430 & 4.2 & [54] \\
\hline $\begin{array}{l}\text { Fluoxetine } \\
\text { depressant) }\end{array}$ & MW & $\begin{array}{l}\text { Prozac, } \\
\text { Sarafem }\end{array}$ & 4.05 & 10,800 & 9.4 & {$[39,44,58]$} \\
\hline $\begin{array}{l}\text { Propranolol (beta- } \\
\text { blocker) }\end{array}$ & $M W=259.3$ & Inderal & 3.12 & 609 & 9.5 & {$[54,59]$} \\
\hline
\end{tabular}


Table 2. Chronic data used in carbamazepine guideline derivation

\begin{tabular}{|c|c|c|c|c|c|c|c|c|c|c|c|}
\hline $\begin{array}{l}\text { Taxonomic } \\
\text { group }\end{array}$ & Common name & Scientific name & Life stage & $\begin{array}{c}\text { Exposure } \\
\text { duration } \\
\text { (d) }\end{array}$ & $\begin{array}{c}\text { Test } \\
\text { medium }\end{array}$ & Test endpoint & $\begin{array}{l}\text { Toxicity } \\
\text { estimate }\end{array}$ & $\begin{array}{l}\text { Toxicity } \\
\text { value } \\
\text { (mg/L) }\end{array}$ & pH & $\begin{array}{c}\text { Temp } \\
\left({ }^{\circ} \mathrm{C}\right)\end{array}$ & Reference \\
\hline $\begin{array}{l}\text { Blue-green } \\
\text { algae }\end{array}$ & $\begin{array}{l}\text { Blue-green } \\
\text { algae }\end{array}$ & $\begin{array}{l}\text { Synechococcus } \\
\text { leopolensis }\end{array}$ & - & 4 & $\begin{array}{l}\text { Moderately } \\
\text { hard water }\end{array}$ & $\begin{array}{l}\text { Growth } \\
\text { inhibition }\end{array}$ & NOEC & 17.5 & & & {$[54]$} \\
\hline Green algae & Green algae & $\begin{array}{l}\text { Pseudokirchneri } \\
\text { ella subcapitata }\end{array}$ & - & 4 & Freshwater & $\begin{array}{l}\text { Growth } \\
\text { inhibition }\end{array}$ & NOEC & 0.52 & & & {$[60]$} \\
\hline Green algae & Green algae & $\begin{array}{l}\text { Chlorella } \\
\text { vulgaris }\end{array}$ & - & 2 & Freshwater & $\begin{array}{l}\text { Growth } \\
\text { inhibition }\end{array}$ & EC10 & $13^{\mathrm{a}}$ & & 22 & {$[61]$} \\
\hline Arthropoda & Midge & $\begin{array}{l}\text { Chironomus } \\
\text { tepperi }\end{array}$ & Embryo & 7 & Freshwater & Larval survival & EC10 & 4.0 & & & {$[5]$} \\
\hline Diatom & Diatom & $\begin{array}{l}\text { Cyclotella } \\
\text { meneghiniana }\end{array}$ & - & 4 & Freshwater & $\begin{array}{l}\text { Growth } \\
\text { inhibition }\end{array}$ & NOEC & 10.0 & & & {$[54]$} \\
\hline Rotifer & Rotifer & $\begin{array}{l}\text { Brachionus } \\
\text { calyciflorus }\end{array}$ & - & 2 & Freshwater & Reproduction & NOEC & 0.38 & & & {$[54]$} \\
\hline Cnidarian & Cnidarian & Hydra attenuate & & 3 & Freshwater & $\begin{array}{l}\text { Morphology } \\
\text { changes }\end{array}$ & NOEC & $\mathbf{1}$ & 7 & 20 & {$[62]$} \\
\hline Crustacean & Water flea & $\begin{array}{l}\text { Ceriodaphnia } \\
\text { dubia }\end{array}$ & - & 7 & Freshwater & Reproduction & NOEC & 0.025 & & & {$[54]$} \\
\hline Crustacean & Water flea & Daphnia magna & & 21 & Freshwater & Reproduction & NOEC & 0.4 & & & {$[22,63]$} \\
\hline Fish & Zebrafish & Danio rerio & Embryo & 10 & & Mortality & NOEC & 25 & & 23 & {$[54]$} \\
\hline Fish & Golden perch & $\begin{array}{l}\text { Macquaria } \\
\text { ambigua }\end{array}$ & Embryo & 7 & Freshwater & Larval survival & EC10 & 1.1 & & & [5] \\
\hline
\end{tabular}

Estimated from dose-response curve 
Table 3. Chronic data used to derive diclofenac guideline

\begin{tabular}{|c|c|c|c|c|c|c|c|c|c|c|c|}
\hline $\begin{array}{l}\text { Taxonomic } \\
\text { group }\end{array}$ & Common name & Scientific name & Life stage & $\begin{array}{c}\text { Exposure } \\
\text { duration } \\
\text { (d) }\end{array}$ & $\begin{array}{c}\text { Test } \\
\text { medium }\end{array}$ & Test endpoint & $\begin{array}{l}\text { Toxicity } \\
\text { estimate }\end{array}$ & $\begin{array}{c}\text { Toxicity } \\
\text { value } \\
(\mathrm{mg} / \mathrm{L})\end{array}$ & pH & $\begin{array}{c}\text { Temp } \\
\left({ }^{\circ} \mathrm{C}\right)\end{array}$ & Reference \\
\hline $\begin{array}{l}\text { Blue-green } \\
\text { algae }\end{array}$ & $\begin{array}{l}\text { Blue-green } \\
\text { algae }\end{array}$ & $\begin{array}{l}\text { Synechococcus } \\
\text { leopolensis }\end{array}$ & - & 4 & $\begin{array}{l}\text { Moderately } \\
\text { hard water }\end{array}$ & $\begin{array}{l}\text { Growth } \\
\text { inhibition }\end{array}$ & NOEC & 10 & & & [54] \\
\hline Green algae & Green algae & $\begin{array}{l}\text { Pseudokirchneri } \\
\text { ella subcapitata }\end{array}$ & - & 4 & $\begin{array}{l}\text { Moderately } \\
\text { hard water }\end{array}$ & $\begin{array}{c}\text { Growth } \\
\text { inhibition }\end{array}$ & NOEC & 10 & & & [54] \\
\hline Green algae & Green algae & $\begin{array}{l}\text { Desmodesmus } \\
\text { subspicatus }\end{array}$ & - & 3 & Freshwater & $\begin{array}{l}\text { Growth } \\
\text { inhibition }\end{array}$ & NOEC & 50 & & & [64] \\
\hline Arthropod & Midge & $\begin{array}{l}\text { Chironomus } \\
\text { tepperi }\end{array}$ & Embryo & 7 & Freshwater & Larval survival & EC10 & 0.76 & & & {$[5]$} \\
\hline Angiosperm & Duckweed & Lemna minor & - & & & $\begin{array}{l}\text { Growth } \\
\text { inhibition }\end{array}$ & NOEC & 3.5 & & & {$[5]$} \\
\hline Diatom & Diatom & $\begin{array}{l}\text { Cyclotella } \\
\text { meneghiniana }\end{array}$ & - & 4 & Freshwater & $\begin{array}{l}\text { Growth } \\
\text { inhibition }\end{array}$ & NOEC & 10.0 & & & {$[54]$} \\
\hline Rotifer & Rotifer & $\begin{array}{l}\text { Brachionus } \\
\text { calyciflorus }\end{array}$ & - & 2 & Freshwater & Reproduction & NOEC & 12.5 & & & [54] \\
\hline Crustacean & Water flea & $\begin{array}{l}\text { Ceriodaphnia } \\
\text { dubia }\end{array}$ & - & 7 & Freshwater & Reproduction & NOEC & 1.0 & & & {$[54]$} \\
\hline Crustacean & Water flea & Daphnia magna & - & 21 & $\begin{array}{l}\text { Reconstitute } \\
\mathrm{d} \text { hard water }\end{array}$ & Reproduction & NOEC & 10 & 7.8 & 25 & {$[65]$} \\
\hline Fish & Zebrafish & Danio rerio & Embryo & 10 & Freshwater & Mortality & NOEC & 4.0 & & 23 & {$[54]$} \\
\hline Fish & Golden perch & $\begin{array}{l}\text { Macquaria } \\
\text { ambigua }\end{array}$ & Embryo & 7 & Freshwater & Larval survival & EC10 & 5.92 & & & [5] \\
\hline
\end{tabular}


Table 4. Chronic data used to derive the fluoxetine guideline

\begin{tabular}{|c|c|c|c|c|c|c|c|c|c|c|c|}
\hline $\begin{array}{l}\text { Taxonomic } \\
\text { group }\end{array}$ & Common name & Scientific name & Life stage & $\begin{array}{c}\text { Exposure } \\
\text { duration } \\
\text { (d) }\end{array}$ & $\begin{array}{c}\text { Test } \\
\text { medium }\end{array}$ & Test endpoint & $\begin{array}{l}\text { Toxicity } \\
\text { estimate }\end{array}$ & $\begin{array}{c}\text { Toxicity } \\
\text { value } \\
(\mu \mathrm{g} / \mathrm{L})\end{array}$ & pH & $\begin{array}{c}\text { Temp } \\
\left({ }^{\circ} \mathrm{C}\right)\end{array}$ & Reference \\
\hline Chlorophyta & Green alga & $\begin{array}{l}\text { Pseudokirchneri } \\
\text { ella subcapitata }\end{array}$ & - & 4 & $\begin{array}{l}\text { Moderately } \\
\text { hard water }\end{array}$ & $\begin{array}{l}\text { Growth } \\
\text { inhibition }\end{array}$ & IC10 & 31.3 & 7.3 & 25 & {$[66]$} \\
\hline Chlorophyta & Green alga & $\begin{array}{l}\text { Pseudokirchneri } \\
\text { ella subcapitata }\end{array}$ & - & 4 & $\begin{array}{l}\text { Moderately } \\
\text { hard water }\end{array}$ & $\begin{array}{l}\text { Growth } \\
\text { inhibition }\end{array}$ & LOEC & 13.6 & - & 25 & {$[47]$} \\
\hline Chlorophyta & Green alga & $\begin{array}{l}\text { Pseudokirchneri } \\
\text { ella subcapitata }\end{array}$ & - & 4 & $\begin{array}{l}\text { Moderately } \\
\text { hard water }\end{array}$ & $\begin{array}{l}\text { Growth } \\
\text { inhibition }\end{array}$ & IC50 & 27 & $\begin{array}{l}8.1- \\
8.5\end{array}$ & $18-22$ & [67] \\
\hline Chlorophyta & Green alga & $\begin{array}{l}\text { Pseudokirchneri } \\
\text { ella subcapitata }\end{array}$ & - & 5 & $\begin{array}{l}\text { Moderately } \\
\text { hard water }\end{array}$ & $\begin{array}{l}\text { Growth } \\
\text { inhibition }\end{array}$ & IC50 & $\begin{array}{c}24 \text { (turb) } \\
39 \text { (cell } \\
\text { dens) }\end{array}$ & - & 25 & {$[48]$} \\
\hline Chlorophyta & Green alga & $\begin{array}{l}\text { Scenedesmus } \\
\text { acutis }\end{array}$ & - & 4 & $\begin{array}{l}\text { Moderately } \\
\text { hard water }\end{array}$ & $\begin{array}{l}\text { Growth } \\
\text { inhibition }\end{array}$ & IC10 & 56 & 7.3 & 25 & {$[66]$} \\
\hline Chlorophyta & Green alga & $\begin{array}{l}\text { Scenedesmus } \\
\text { quadricauta }\end{array}$ & - & 4 & $\begin{array}{l}\text { Moderately } \\
\text { hard water }\end{array}$ & $\begin{array}{l}\text { Growth } \\
\text { inhibition }\end{array}$ & IC10 & $98^{\mathrm{a}}$ & 7.3 & 25 & {$[66]$} \\
\hline Chlorophyta & Green alga & $\begin{array}{l}\text { Desmodesmus } \\
\text { subspicatus }\end{array}$ & - & 4 & $\begin{array}{l}\text { Moderately } \\
\text { hard water }\end{array}$ & $\begin{array}{l}\text { Growth } \\
\text { inhibition }\end{array}$ & IC10 & 1.0 & & & [39] \\
\hline Chlorophyta & Green alga & $\begin{array}{l}\text { Chlorella } \\
\text { vulgaris }\end{array}$ & - & 4 & $\begin{array}{l}\text { Moderately } \\
\text { hard water }\end{array}$ & $\begin{array}{l}\text { Growth } \\
\text { inhibition }\end{array}$ & IC10 & 2900 & 7.3 & 25 & {$[66]$} \\
\hline Chlorophyta & Green alga & $\begin{array}{l}\text { Dunaliella } \\
\text { tertiolecta }\end{array}$ & & 4 & $\begin{array}{l}\text { Moderately } \\
\text { hard water }\end{array}$ & $\begin{array}{l}\text { Growth } \\
\text { inhibition }\end{array}$ & IC10 est & $24^{\mathrm{a}}$ & - & 25 & {$[68]$} \\
\hline Arthropod & Midge & $\begin{array}{l}\text { Chironomus } \\
\text { tepperi }\end{array}$ & Embryo & 7 & $\begin{array}{l}\text { Moderately } \\
\text { hard water }\end{array}$ & Larval survival & EC10 & 59 & & & {$[5]$} \\
\hline Angiosperm & Duckweed & Lemna minor & - & $?$ & $\begin{array}{l}\text { Moderately } \\
\text { hard water }\end{array}$ & $\begin{array}{l}\text { Growth } \\
\text { inhibition }\end{array}$ & EC10 & 1190 & & & {$[5]$} \\
\hline Crustacean & Amphipod & Hyalella azteca & - & 28 & $\begin{array}{l}\text { Moderately } \\
\text { hard water }\end{array}$ & $\begin{array}{l}\text { Growth } \\
\text { inhibition }\end{array}$ & NOEC & 13 & 7.9 & 20 & {$[40]$} \\
\hline Crustacean & Water flea & $\begin{array}{l}\text { Ceriodaphnia } \\
\text { dubia }\end{array}$ & - & 7 & $\begin{array}{l}\text { Moderately } \\
\text { hard water }\end{array}$ & Reproduction & NOEC & 56 & - & 25 & [48] \\
\hline Crustacean & Water flea & $\begin{array}{l}\text { Ceriodaphnia } \\
\text { dubia }\end{array}$ & - & 7 & $\begin{array}{l}\text { Moderately } \\
\text { hard water }\end{array}$ & Reproduction & NOEC & 89 & & 25 & [69] \\
\hline
\end{tabular}




\begin{tabular}{|c|c|c|c|c|c|c|c|c|c|c|c|}
\hline & & & & & & & GM & 71 & & & \\
\hline Crustacean & Water flea & Daphnia magna & - & 21 & $\begin{array}{l}\text { Moderately } \\
\text { hard water }\end{array}$ & Reproduction & NOEC & 174 & 8.4 & 25 & [43] \\
\hline Crustacean & Water flea & Daphnia magna & - & 21 & $\begin{array}{l}\text { Moderately } \\
\text { hard water }\end{array}$ & Reproduction & NOEC & 8.9 & 7.9 & 20 & [40] \\
\hline \multirow[t]{2}{*}{ Crustacean } & Water flea & Daphnia magna & - & 21 & $\begin{array}{l}\text { Moderately } \\
\text { hard water }\end{array}$ & Reproduction & NOEC & 60 & & & [39] \\
\hline & & & & & & & GM & 45.3 & & & \\
\hline Gastropod & $\begin{array}{l}\text { New Zealand } \\
\text { mud snail }\end{array}$ & $\begin{array}{l}\text { Potamopyrgus } \\
\text { antipodarum }\end{array}$ & Embryo & 56 & $\begin{array}{l}\text { Moderately } \\
\text { hard water }\end{array}$ & Survival & EC10 & 0.89 & - & 16 & [41] \\
\hline \multirow[t]{2}{*}{ Gastropod } & $\begin{array}{l}\text { New Zealand } \\
\text { mud snail }\end{array}$ & $\begin{array}{l}\text { Potamopyrgus } \\
\text { antipodarum }\end{array}$ & Embryo & 42 & $\begin{array}{l}\text { Moderately } \\
\text { hard water }\end{array}$ & Reproduction & NEC & 5 & & & [40] \\
\hline & & & & & & & GM & 2.0 & & & \\
\hline Amphibia & $\begin{array}{l}\text { African clawed } \\
\text { frog }\end{array}$ & Xenopus laevis & Embryo & 4 & Hard water & Malformation $^{\mathrm{b}}$ & EC10 & 3000 & 7.6 & 23 & [42] \\
\hline Fish & $\begin{array}{l}\text { Fathead } \\
\text { minnow }\end{array}$ & $\begin{array}{l}\text { Pimephales } \\
\text { promelas }\end{array}$ & Juvenile & 7 & $\begin{array}{l}\text { Moderately } \\
\text { hard water }\end{array}$ & Growth $^{\mathrm{c}}$ & EC10 & 9 & 8.4 & 25 & [43] \\
\hline Fish & Golden perch & $\begin{array}{l}\text { Macquaria } \\
\text { ambigua }\end{array}$ & Embryo & 7 & Freshwater & Larval survival & EC10 & 260 & & & {$[5]$} \\
\hline
\end{tabular}

${ }^{a}$ Estimated from the published dose response curve; ${ }^{b}$ Not an acceptable endpoint as many factors can lead to malformations; ${ }^{c}$ Juvenile growth must be measured over 21 days 
Table 5. Chronic data used to derive the propranolol guideline

\begin{tabular}{|c|c|c|c|c|c|c|c|c|c|c|c|}
\hline $\begin{array}{l}\text { Taxonomic } \\
\text { group }\end{array}$ & Common name & Scientific name & Life stage & $\begin{array}{c}\text { Exposure } \\
\text { duration } \\
\text { (d) }\end{array}$ & $\begin{array}{c}\text { Test } \\
\text { medium }\end{array}$ & Test endpoint & $\begin{array}{l}\text { Toxicity } \\
\text { estimate }\end{array}$ & $\begin{array}{c}\text { Toxicity } \\
\text { value } \\
(\mathrm{mg} / \mathrm{L})\end{array}$ & pH & $\begin{array}{c}\text { Temp } \\
\left({ }^{\circ} \mathrm{C}\right)\end{array}$ & Reference \\
\hline $\begin{array}{l}\text { Blue-green } \\
\text { algae }\end{array}$ & $\begin{array}{l}\text { Blue-green } \\
\text { algae }\end{array}$ & $\begin{array}{l}\text { Synechococcus } \\
\text { leopolensis }\end{array}$ & - & 4 & $\begin{array}{l}\text { Moderately } \\
\text { hard water }\end{array}$ & $\begin{array}{l}\text { Growth } \\
\text { inhibition }\end{array}$ & NOEC & 0.35 & 7.8 & 23 & {$[54]$} \\
\hline Green algae & Green algae & $\begin{array}{l}\text { Pseudokirchneri } \\
\text { ella subcapitata }\end{array}$ & - & 4 & $\begin{array}{l}\text { Moderately } \\
\text { hard water }\end{array}$ & $\begin{array}{l}\text { Growth } \\
\text { inhibition }\end{array}$ & NOEC & 5 & 7.8 & 23 & {$[54]$} \\
\hline \multirow[t]{2}{*}{ Green algae } & Green algae & $\begin{array}{l}\text { Pseudokirchneri } \\
\text { ella subcapitata }\end{array}$ & - & 3 & $\begin{array}{l}\text { Deionised } \\
\text { water }\end{array}$ & $\begin{array}{l}\text { Growth } \\
\text { inhibition }\end{array}$ & NOEC & $<0.78$ & - & 24 & {$[70]$} \\
\hline & & & & & & & GM & 2.0 & & & \\
\hline Green algae & Green algae & $\begin{array}{l}\text { Desmodesmus } \\
\text { subspicatus }\end{array}$ & - & 3 & $\begin{array}{l}\text { Moderately } \\
\text { hard water }\end{array}$ & $\begin{array}{l}\text { Growth } \\
\text { inhibition }\end{array}$ & $\begin{array}{c}\text { EC5 } \\
\text { EC10 }\end{array}$ & $\begin{array}{l}0.18 \\
0.33\end{array}$ & 7.8 & 23 & {$[52]$} \\
\hline Arthropod & Midge & $\begin{array}{l}\text { Chironomus } \\
\text { tepperi }\end{array}$ & Embryo & 7 & $\begin{array}{l}\text { Moderately } \\
\text { hard water }\end{array}$ & Larval survival & EC10 & 2.06 & & & [5] \\
\hline Angiosperm & Duckweed & Lemna minor & - & $?$ & $\begin{array}{l}\text { Moderately } \\
\text { hard water }\end{array}$ & $\begin{array}{l}\text { Growth } \\
\text { inhibition }\end{array}$ & EC10 & 29.5 & & & [5] \\
\hline Diatom & Diatom & $\begin{array}{l}\text { Cyclotella } \\
\text { meneghiniana }\end{array}$ & - & 4 & $\begin{array}{l}\text { Moderately } \\
\text { hard water }\end{array}$ & $\begin{array}{l}\text { Growth } \\
\text { inhibition }\end{array}$ & NOEC & 0.094 & 7.8 & 23 & {$[54]$} \\
\hline Rotifer & Rotifer & $\begin{array}{l}\text { Brachionus } \\
\text { calyciflorus }\end{array}$ & - & 2 & $\begin{array}{l}\text { Moderately } \\
\text { hard water }\end{array}$ & Reproduction & NOEC & 0.18 & 7.8 & 23 & {$[54]$} \\
\hline Rotifer & Rotifer & $\begin{array}{l}\text { Brachionus } \\
\text { calyciflorus }\end{array}$ & - & 2 & $\begin{array}{l}\text { Deionised } \\
\text { water }\end{array}$ & Reproduction & NOEC & 1.0 & - & 24 & {$[70]$} \\
\hline Crustacean & Water flea & $\begin{array}{l}\text { Ceriodaphnia } \\
\text { dubia }\end{array}$ & - & 7 & $\begin{array}{l}\text { Moderately } \\
\text { hard water }\end{array}$ & Reproduction & NOEC & 0.009 & 7.8 & 23 & {$[54]$} \\
\hline \multirow[t]{2}{*}{ Crustacean } & Water flea & $\begin{array}{l}\text { Ceriodaphnia } \\
\text { dubia }\end{array}$ & - & 7 & $\begin{array}{l}\text { Reconstitute } \\
\mathrm{d} \text { hard water }\end{array}$ & Reproduction & NOEC & 0.125 & & 25 & [71] \\
\hline & & & & & & & GM & 0.033 & & & \\
\hline Crustacean & Water flea & Daphnia magna & - & 9 & Hard water & Reproduction & NOEC & 0.055 & - & 25 & {$[72]$} \\
\hline Fish & Rainbow trout & Oncorhynchus & Juvenile & 40 & $\begin{array}{l}\text { Moderately } \\
\text { hard fresh }\end{array}$ & Growth rate & NOEC & $8.7^{\mathrm{a}}$ & 7.4 & 15 & [73] \\
\hline
\end{tabular}




\begin{tabular}{|c|c|c|c|c|c|c|c|c|c|c|c|}
\hline & & mykiss & & & water & & & & & & \\
\hline Fish & $\begin{array}{l}\text { Fathead } \\
\text { minnow }\end{array}$ & $\begin{array}{l}\text { Pimephales } \\
\text { promelas }\end{array}$ & Embryo & 21 & $\begin{array}{l}\text { Dechlorinat } \\
\text { ed tap water }\end{array}$ & Hatchability & NOEC & 0.01 & 7.5 & 25 & [53] \\
\hline Fish & Golden perch & $\begin{array}{l}\text { Macquaria } \\
\text { ambigua }\end{array}$ & Embryo & 7 & Freshwater & Larval survival & EC10 & 4.9 & & & {$[5]$} \\
\hline
\end{tabular}

${ }^{a}$ Corrected for analytical recovery data 
Table 6. Derived water quality guidelines for the 4 pharmaceuticals

\begin{tabular}{lccc}
\hline \multicolumn{1}{c}{ Pharmaceutical } & PC99 & $\begin{array}{c}\text { PC95 } \\
\boldsymbol{\mu g} / \mathbf{L}\end{array}$ & PC90 \\
\hline Carbamazepine & $<1$ & 4.3 & 32 \\
Diclofenac & 180 & 770 & 1400 \\
Fluoxetine & 0.23 & 1.6 & 3.8 \\
Propranolol & 3.5 & 14 & 29 \\
\hline
\end{tabular}

Table 7. Comparison of derived GVs with other international values

\begin{tabular}{lccccc}
\hline Pharmaceutical & EC EQS $^{\mathbf{a}}$ & $\begin{array}{c}\text { Switzerland } \\
\text { EQS }^{\mathbf{b}}\end{array}$ & $\begin{array}{c}\text { German } \\
\text { EQS }^{\mathbf{c}}\end{array}$ & $\begin{array}{c}\text { Other } \\
\text { values }\end{array}$ & This study $^{\mathbf{d}}$ \\
\cline { 2 - 6 } & \multicolumn{5}{c}{$\boldsymbol{\mu g} / \mathbf{L}$} \\
\hline Carbamazepine & - & 0.5 & 0.5 & $2.1^{\mathrm{d}, \mathrm{e}}$ & 4.3 \\
Diclofenac & 0.1 & 0.05 & 0.05 & $580^{\mathrm{d}, \mathrm{e}}$ & 770 \\
Fluoxetine & - & - & - & $0.004^{\mathrm{f}, \mathrm{g}}$ & 1.6 \\
& & & & $0.012^{\mathrm{f}, \mathrm{h}}$ & \\
& & & $0.031^{\mathrm{f}, \mathrm{i}}$ & \\
Propranolol & - & 0.16 & - & $0.05^{\mathrm{f,j}}$ & 14 \\
\hline
\end{tabular}

${ }^{\mathrm{a}}[74] ;{ }^{\mathrm{b}}[32] ;{ }^{\mathrm{c}}[21] ;{ }^{\mathrm{d}} \mathrm{HC}$ (95\% species protection) ${ }^{\mathrm{e}}[23] ;{ }^{\mathrm{f}}$ PNEC values;

${ }^{\mathrm{g}}[50] ;{ }^{\mathrm{h}}[39] ;{ }^{\mathrm{h}}[49] ;{ }^{\mathrm{j}}[2]$ 

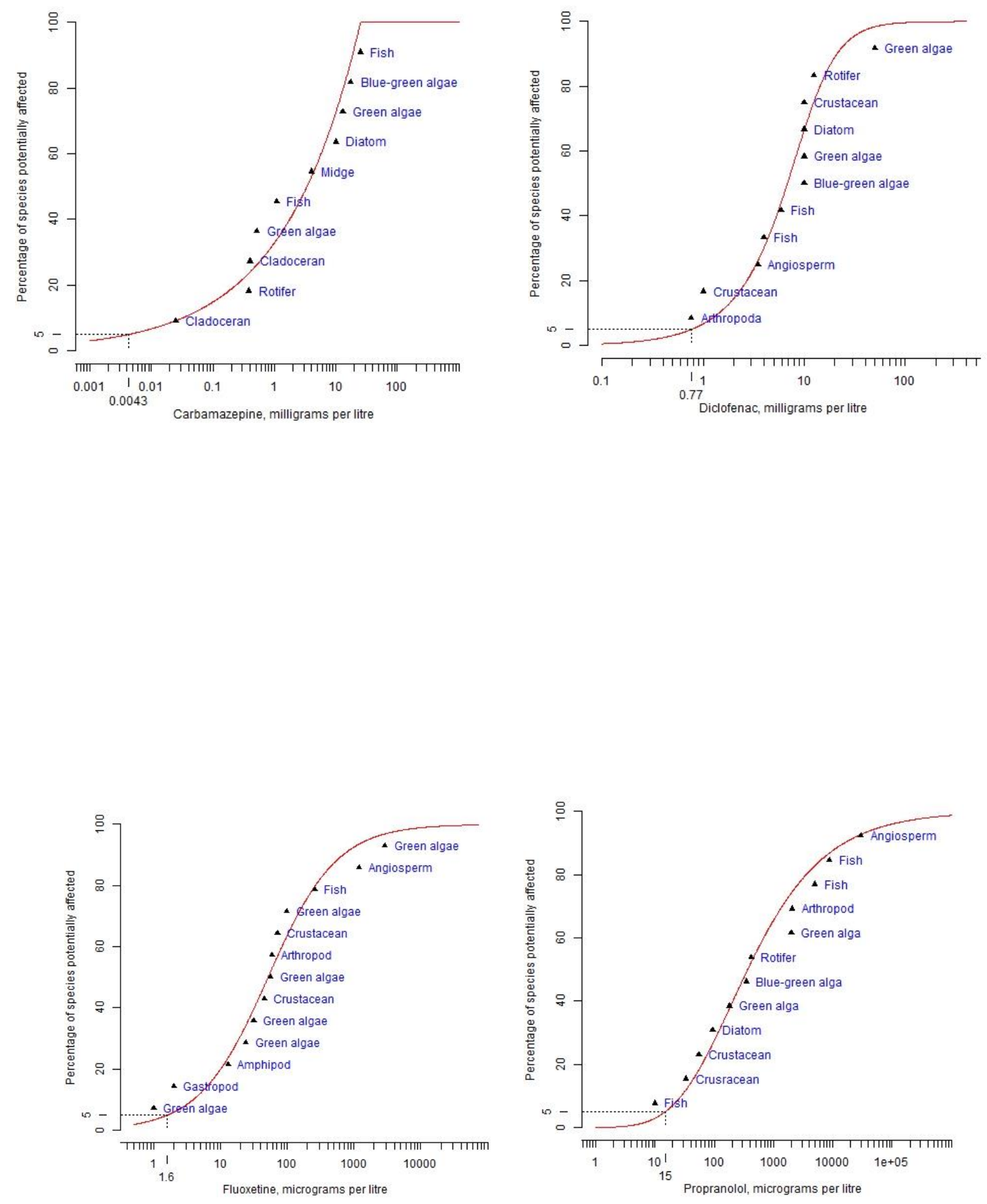

Figure 1. SSDs for carbamazepine, diclofenac, fluoxetine and propranolol 
